\title{
Social Deficits, Stereotypy, and Early Emergence of Repetitive Behavior in the C58/J Inbred Mouse Strain
}

\author{
Bryce C. Ryan $a, b,{ }^{*}$, Nancy B. Young ${ }^{b}$, Jacqueline N. Crawley ${ }^{b, c}$, James W. Bodfish ${ }^{b, d, e}$, and \\ Sheryl S. Moyb,e \\ aDepartment of Biology, University of Redlands, Redlands, CA 92373 \\ bNeurodevelopmental Disorders Research Center, University of North Carolina School of Medicine, \\ Chapel Hill, NC 27599 USA \\ 'Laboratory of Behavioral Neuroscience, Intramural Research Program, National Institute of Mental \\ Health, Bethesda, MD 20892-3730 USA \\ ${ }^{d}$ Clinical Center for the Study of Development and Learning, University of North Carolina School of \\ Medicine, Chapel Hill, NC 27599 \\ eDepartment of Psychiatry, University of North Carolina School of Medicine, Chapel Hill, NC 27599 \\ USA
}

\begin{abstract}
Mouse lines with behavioral phenotypes relevant to symptoms in neurodevelopmental disorders may provide models to test hypotheses about disease etiology and to evaluate potential treatments. The present studies were designed to confirm and expand earlier work on the intriguing behavioral profile of the C58/J inbred strain, including low social approach and aberrant repetitive movements. Additional tests were selected to reflect aspects of autism, a severe neurodevelopmental disorder characterized by emergence of symptoms early in life, higher prevalence in males, social deficits and abnormal repetitive behavior. Mice from the C57BL/6J inbred strain, which has a similar genetic lineage and physical appearance to C58/J, served as a comparison group. Our results revealed that C58/J mice display elevated activity levels by postnatal day 6 , which persist into adulthood. Despite normal olfactory ability, young adult male C58/J mice showed deficits in social approach in the threechambered choice assay and failed to demonstrate social transmission of food preference. In contrast, female C58/J mice performed similarly to female C57BL/6J mice in both social tests. C58/J mice of both sexes demonstrated abnormal repetitive behaviors, displaying excessive jumping and back flipping in both social and non-social situations. These stereotypies were clearly evident in C58/J pups by postnatal days $20-21$, and were also observed in C58/J dams during a test for maternal behavior. Overall, the strain profile for $\mathrm{C} 58 / \mathrm{J}$, including spontaneously developing motor stereotypies emerging early in the developmental trajectory, and social deficits primarily in males, models multiple components of the autism phenotype.
\end{abstract}

(C) 2009 Elsevier B.V. All rights reserved.

*Corresponding author: Department of Biology, University of Redlands, 1200 East Colton Avenue, PO Box 3080, Redlands, CA 92373-0999, Phone: (909) 748-8518, Fax: (909) 355-5312, bryce_ryan@redlands.edu.

Publisher's Disclaimer: This is a PDF file of an unedited manuscript that has been accepted for publication. As a service to our customers we are providing this early version of the manuscript. The manuscript will undergo copyediting, typesetting, and review of the resulting proof before it is published in its final citable form. Please note that during the production process errors may be discovered which could affect the content, and all legal disclaimers that apply to the journal pertain. 


\section{Keywords}

Autism; Social transmission of food preference; Maternal behavior; Neonatal development; Olfaction; Repetitive behavior, Social approach; Stereotypy

\section{Introduction}

Mouse models of behavioral symptoms in human disease can be used to study the underlying neurobiology of aberrant phenotypes and to evaluate potential therapeutic strategies. For this reason, our laboratory has screened a number of inbred mouse strains and mutant lines for the presence of behaviors that may reflect symptoms seen in autism, fragile $\times$ syndrome, and other clinical disorders [10,35,36,37]. In these initial studies, one inbred strain demonstrated a particularly interesting behavioral profile [37]. Male C58/J mice demonstrated a lack of sociability in a three-chambered choice assay, and also showed overt stereotypy in several testing paradigms. Impaired social interaction, communication deficits, and abnormal repetitive behaviors are core features of autism [31]. The goal of this study was to confirm our initial findings, and to determine whether the C58/J mouse model reflects additional components of the autism phenotype.

Our previous study on the C58/J strain examined behavior in adolescent and adult animals. However, autism is a neurodevelopmental disorder with symptoms emerging early in childhood [25,31]. A mouse model of autistic-like behavior would ideally recapitulate the emergence of abnormal behavior early in life. To address this issue, we utilized a neonatal screen to evaluate motor function, activity levels, and the emergence of stereotypy in C58/J pups throughout the lactational period of development, starting at 6 days of age. Both male and female mice were assessed, to determine if the rates of aberrant repetitive behavior reflected the higher prevalence of autism in boys than in girls (with a ratio of approximately 4:1) [25, 39]. For these studies, the behavioral profiles of the $\mathrm{C} 58 / \mathrm{J}$ mice were compared to profiles of C57BL/6J mice, since this inbred strain shares a common genetic lineage with C58/J [14]. The two strains have an almost identical physical appearance and are available commercially from the same supplier, suggesting that $\mathrm{C} 57 \mathrm{BL} / 6 \mathrm{~J}$ can serve as an appropriate control for C58/J. In addition to the neonatal screen, measures were taken of maternal responses, in order to determine if C58/J dams have an abnormal behavioral phenotype in comparison to control dams.

Male C58/J mice have low sociability in a three-chambered choice task that presents the subject mouse with a choice between spending time with a novel mouse or spending time with a novel nonsocial object [37]. To extend this earlier finding, we tested both male and female mice in the three-chambered assay and in a social transmission of food preference (STFP) task. The STFP task measures aspects of rodent social communication between conspecifics $[6,15,23$, $34,50,55,59,60]$. Rodents are naturally neophobic, and will avoid a completely novel food. However, mice will readily consume food previously smelled and/or tasted on the breath, muzzle, and whiskers of a conspecific. In this assay, the subject "observer" mouse is allowed to freely interact with a "demonstrator" mouse that recently ate a novel flavored food. The subject observer forms a food preference based on cues transferred between the mice during the interaction session.

Olfactory information is a critical component of social preference and interaction in mice $[11,28,29,40,51]$. The olfactory habituation/dishabituation task $[18,33,57]$ tests the ability of a mouse to discriminate between different odors, including olfactory stimuli collected from unfamiliar mice. We used this assay to determine whether C58/J mice have deficiencies in odor discrimination, in comparison to C57BL/6J mice. A finding of altered olfactory function in 
C58/J could be relevant to changes in social approach, social transmission of food preference, and maternal behavior in this strain.

\section{Materials and methods}

\subsection{Animals}

$\mathrm{C} 57 \mathrm{BL} / 6 \mathrm{~J}$ and $\mathrm{C} 58 / \mathrm{J}$ mice for these studies were offspring of breeding pairs obtained from the Jackson Laboratory (Bar Harbor, ME) and maintained in a vivarium at the University of North Carolina at Chapel Hill. All mice were weaned on postnatal day 21 and subsequently housed with same-sex littermates. Animals were maintained on a 12L:12D circadian schedule with lights on at 7AM. The housing room was maintained at $20-24^{\circ} \mathrm{C}$ and $40 \%-50 \%$ relative humidity. Dams were fed ad libitum on Purina PicoLab Mouse Diet 20. Adults and weaned pups were fed ad libitum on Purina ProLab IsoPro 3000. Mice were housed in standard $20 \mathrm{~cm}$ $\times 30 \mathrm{~cm}$ ventilated polycarbonate cages containing laboratory grade Bed-O-Cob bedding and were given water ad libitum. A small section of PVC pipe was present in each cage for enrichment. All breeding and testing procedures were conducted in strict compliance with the "Guide for the Care and Use of Laboratory Animals" (Institute of Laboratory Animal Resources, National Research Council, 1996) and approved by the Institutional Animal Care and Use Committee of the University of North Carolina.

Two different cohorts of mice were used in this project. This first cohort consisted of eleven C57BL/6J and seven C58/J dams and litters, which were tested in the neonatal screen, the juvenile motor activity and maternal behavior assays. This testing was completed by the time the pups reached weaning age at postnatal day (PND) 21 and these litters were not used in any other behavioral experiments. The second cohort consisted of C57BL/6J (16 male and 14 female) and C58/J (26 male and 18 female) mice and was tested in the olfactory habituation/ dishabituation, three-chambered social choice and social transmission of food preference tasks. Beginning at approximately PND 30, the mice were tested in all three assays in the order described here, with a one-week break between testing. Light levels for each behavioral test ranged from 570-620 1×, except where noted. In every assay, the experimenter was blind to the strain of the animal being tested.

\subsection{Neonatal motor screen}

Breeding pairs were checked daily for new litters. When a new litter was observed, the number of pups was counted and the litter was considered to be on PND 1. Both the dam and sire were kept in the cage with the pups throughout the neonatal period. On PNDs 6, 8 and 10, the pups were removed from their home cage, placed into a warmed beaker $\left(35^{\circ} \mathrm{C}\right.$; with temperature regulated via a hotplate analgesia meter, IITC Life Sciences Inc, Woodland Hills, CA) and tested in the following neurobehavioral screen (adapted from [8]):

2.2.1. Negative geotaxis-A $20 \mathrm{~cm} \times 20 \mathrm{~cm}$ screen with $0.5 \mathrm{~cm}$ wire mesh squares was set at a $25^{\circ}$ angle. Each pup was placed downward on the screen with its head facing toward the bottom, allowed to grip the mesh, and then released. The time it took for each pup to turn $180^{\circ}$ (head and upper torso vertical), was recorded, with a $30 \mathrm{sec}$ maximum. This procedure was repeated three times, and the lowest latency to turn was used for the data analysis.

2.2.2. Righting -Each pup was placed onto its back on a flat Plexiglas surface. The experimenter gently held the pup in place for $2 \mathrm{sec}$ and then released it. The latency to righting (all four feet on the ground) was timed, with a maximum of $30 \mathrm{sec}$.

2.2.3. Forward locomotion-Each pup was placed into the center of a $20 \mathrm{~cm} \times 20 \mathrm{~cm}$ Plexiglas chamber with a grid of $2 \mathrm{~cm} \times 2 \mathrm{~cm}$ squares drawn beneath the floor. The number 
of pivots (circling or lateral movement, as opposed to forward locomotion) was recorded. The amount of time spent moving forward and the number of squares crossed after 3 min was also recorded, as was any jumping or rearing.

Each pup was screened through the three assays in the order presented here. After finishing the neonatal motor screen, each pup was weighed, sexed, marked with a non-toxic Sharpie, and placed back into the warm beaker. The wire mesh screen and Plexiglas chamber were wiped down with water and dried with a paper towel between each mouse, and cleaned with alcohol at the end of each testing day.

\subsection{Motor activity}

On PND 16 or 17 and then again on PND 20 or 21, the litter was removed from the home cage and placed into a beaker. One at a time, each pup was placed into the center of an empty PhenoTyper box $(30.5 \mathrm{~cm} \times 30.5 \mathrm{~cm} \times 43.5 \mathrm{~cm}$; Noldus Information Technology, Wageningen, The Netherlands). The PhenoTyper was placed within a sound-attenuating chamber to limit any visual or auditory distractions during the trial. A dim yellow light ( $301 \times)$ within the top of the PhenoTyper box was illuminated throughout the trial. The mouse was allowed to acclimate to the apparatus for $30 \mathrm{sec}$ and then freely explore for $10 \mathrm{~min}$. The integrated camera system in the PhenoTyper was connected to a computer and the video was scored in real time using EthoVision 3.1 tracking software (Noldus Information Technology, Wageningen, The Netherlands). Using this software, the arena was divided into four different zones: corners $(2 \mathrm{~cm}$ $\times 2 \mathrm{~cm}$ squares), walls (the outer $2 \mathrm{~cm}$ of the arena, not counting the corners), center ( $4 \mathrm{~cm} \times$ $4 \mathrm{~cm}$ square in the very center of the arena), and the mid-area (the rest of the arena). EthoVision was used to automatically calculate the amount of time spent in each zone and the distance moved during the $10 \mathrm{~min}$ trial. In addition to these measures, the experimenter viewed the trial in real time on a computer screen and recorded the number and duration of any self grooming, jumping, or rearing bouts. After finishing the assay, the pup was weighed, sexed, marked with a Sharpie, and returned to the beaker. The PhenoTyper box was wiped down with water and dried with a paper towel after every trial, and cleaned with alcohol at the end of each testing day.

\subsection{Maternal behavior}

On PND 3, 6, 8, 10, 13, 16 or 17 and 20 or 21, the dam was tested for maternal behavior, for a total of 7 maternal behavior tests. The pups were removed from the home cage and placed into a beaker (warmed on PNDs 3, 6, 8 and 10). The dam was also removed from the home cage and placed into a new cage with clean bedding and a nestlet cotton square (Ancare Corp., Bellmore, NY; $5 \mathrm{~cm} \times 5 \mathrm{~cm} \times 0.5 \mathrm{~cm}$ ), and closed with a wire lid. During the period of separation, the pups either had their motor reflexes tested (PND 6, 8 and 10), had their activity assayed (PND 16 or 17 and 20 or 21) as described above, or remained in the beaker for $10 \mathrm{~min}$ (PND 3 and 13). To begin the maternal behavior assay, the pups were gently placed into the new cage with the dam. The pups were arranged in a group as far away from the nestlet material as possible. The experimenter then recorded the amount of time the dam spent in close proximity to the pups and noted the occurrence of multiple behaviors (adapted from [26]), listed in Table 1 (repetitive behaviors are defined in section 2.8). Following the 15-min observation period, the sire was placed into the cage with the dam and pups and the cage was returned to the housing room.

\subsection{Olfactory habituation/dishabituation}

Adolescent mice were used in the olfactory habituation/dishabituation assay. Prior to the start of testing, each mouse was placed into a low profile rat-sized cage $(30 \times 60 \times 15 \mathrm{~cm})$ with clean bedding $30 \mathrm{~min}$ prior to testing. After this acclimation period, the olfactory testing began. A $15 \mathrm{~cm}$ cotton swab (Fisher Scientific, Pittsburgh, PA) was dipped in water, slid through the 
top of the cage and held in place with a binder clip. This method positioned the moistened end of the cotton swab approximately $5 \mathrm{~cm}$ above the bedding in the center of the cage. The mouse was observed for $2 \mathrm{~min}$ and any olfactory investigations of the cotton swab were timed. An olfactory investigation was defined as the mouse lifting and orienting its nose to within approximately $2 \mathrm{~cm}$ of the cotton swab tip. Other behaviors such as self-grooming, rearing, jumping, digging in the bedding, eating the bedding, and climbing on or chewing on the cotton swab were manually recorded.

After 2 min, the cotton swab was replaced with a new swab dipped in water. The mouse was again observed for $2 \mathrm{~min}$ and this process was repeated a third time with a new swab dipped in water. Following this pattern, every odor was tested in triplicate fashion in the following order: 3 trials of water alone, 3 trials with a nonsocial stimulus (dilute flavoring extract), 3 trials with a different nonsocial stimulus (a different dilute flavoring extract), 3 trials with a social stimulus (odor from a stranger mouse cage with soiled bedding), and 3 trials with a different social stimulus (odor from a different stranger mouse cage with soiled bedding). Overall, each mouse was exposed to 5 different odors.

For the nonsocial odors, a clean cotton swab was dipped into diluted almond or banana extract (McCormick \& Co. Inc., Sparks, MD; 1:100 in tap water). The extracts were freshly diluted on the morning of testing and the bottled extracts were kept refrigerated between testing days. Order of presentation (almond first or banana first) was counterbalanced across mice. For the social odors, a clean cotton swab was dipped into water and then dragged along the bottom of a soiled cage in a zigzag fashion such that the swab touched all four corners and the middle of the cage. Care was taken to ensure that the zigzag pattern was consistent each time to increase the probability that the swab encountered approximately the same amount of feces and urine each time. Stranger cages housed at least 3 C57BL/6J mice of the same sex as the test animal and had not been changed within the past three days.

\subsection{Three-chambered social choice test}

Behavioral testing was conducted as previously described, under 320-340 1× [38]. On the day of testing, the home cage was brought into the testing room at least 30 min prior to testing. Each mouse was first given 10 min to acclimate to the empty apparatus, with the doors open to all three chambers. Following the habituation session, the mouse was given a test for sociability, with a choice between two objects placed in the side chambers. The social object was an unfamiliar, same-sex C57BL/6J mouse (stranger 1) confined within a wire cage (Galaxy Cup, Spectrum Diversified Designs, Inc., Streetsboro, OH). An empty wire cage served as the non-social novel object. The test mouse was allowed to freely explore all three chambers for $10 \mathrm{~min}$. The number of transitions between chambers and the time spent in each chamber were automatically recorded. The experimenter sat approximately two meters from the chamber and manually scored time spent sniffing each novel object using a computer keyboard. Following the sociability test, mice were given a 10-min test for social novelty preference. A second unfamiliar mouse (stranger 2) was placed into the previously empty wire cage. The subject mouse then had a choice between the new unfamiliar mouse versus the previously-investigated stranger 1 mouse. In between the three test phases, the subject mouse was allowed to sit in the central chamber while the unfamiliar mice were placed into the wire cages. All stranger mice had been previously habituated to the wire container at least once. The social test box was wiped down with water between each trial and cleaned with alcohol at the end of each testing day.

\subsection{Social transmission of food preference}

Behavioral testing was conducted as previously described $[59,60]$. The experimenter scored social interactions with a silent stopwatch and observed from a distance of approximately one 
meter. Twenty-four hours prior to the onset of testing, mouse chow food was removed from the home cage and a specially designed food jar (Dyets Inc., Bethlehem, PA), filled with bedding and topped with powdered chow, was placed into each cage, to acclimate each mouse to the novel feeding apparatus. Eighteen hours prior to testing, the feeding jars were removed and the mice remained food deprived until testing. Thirty minutes prior to testing, the subject mice were brought to the testing room and individually housed in cages with clean bedding.

To begin testing, a "demonstrator" mouse was given a food jar filled with bedding and topped with flavored, powdered chow. The flavored food was prepared by mixing either $1 \%$ ground cinnamon (McCormick \& Co. Inc., Sparks, MD) or 2\% powdered cocoa (The Hershey Co., Hershey, PA) by weight into powdered Purina 5001 rodent chow. The flavored food was mixed fresh on the morning of testing and all ingredients were kept refrigerated between testing days. After $1 \mathrm{hr}$, the food jar was removed and weighed to ensure that at least 0.2 grams of food had been consumed. The demonstrator mouse was then immediately placed into the cage of the "observer" test mouse. Interactions between the demonstrator and the observer were scored for $30 \mathrm{~min}$, and the number of mutual nose sniffs was recorded. Immediately following the 30min interaction period, the demonstrator was removed and two jars of powdered food (one of each flavor) were placed into the cage with the observer mouse. The mouse was scored for 1 $\mathrm{hr}$ and the number of jar climbs and eating bouts were recorded. Additionally, the number of jumps by the observer mouse was also recorded. At the end of the 1-hr choice session, the food jars were removed and weighed. All feeding jars were thoroughly cleaned with soap and hot water in between testing. The demonstrator mice used in this experiment were C57BL/6 J animals matched to the test observer mouse by weight and sex.

\subsection{Repetitive behaviors}

The presence of repetitive behaviors was recorded during the above assays. Two predominant types of repetitive behavior were jumping and back flipping, as previously described in deer mice [44]. Jumping was defined as the mouse rearing on its hind legs in a corner or along a wall and jumping so that all four feet were off the ground simultaneously, often repeatedly ("jackhammer" jumping). Back flipping involved a rapid backward somersault, almost always performed with assistance of the metal-bar cage lid. "Upright scrabbling" was a behavior that, like jumping, occurred against a wall or corner. In an upright position, the mouse appeared to be running or climbing in place. Upright scrabbling may be related to wall-climbing stereotypy, as observed in mice following treatment with apomorphine [48]. Counts were taken of jumping and back flips, while upright scrabbling was measured by bouts, defined as a response occurring for more than one second.

\subsection{Statistics}

PC SAS or Statview (Cary, NC) was used for all statistical analyses. For the neonatal motor screen, scores for analysis were means for each sex from each litter, rather than individual pup scores. One-way or repeated measures Analysis of Variance (ANOVA) were used to determine effects of strain and sex. Separate analyses fo $r$ males and females were then conducted, in order to determine the effects of strain within each sex. Within-strain repeated measures ANOVAs were used to determine side and food preferences in the social behavior assays. Posthoc analyses were conducted with Dunnett's test for individual comparisons or Fisher's Protected Least Significant Differences (PLSD) following a significant ANOVA. MannWhitney $U$ non-parametric tests were used to analyze data from the olfactory habituation assay. Chi-Square tests were used to determine significance of group-proportion data. For all comparisons, significance was set at $p<0.05$. 


\section{Results}

\subsection{Pup body weights and litter size}

Differences in nutrition and maternal care early in life could have a profound impact on pup behavior and survival. However, we did not find overt or consistent strain differences in body weight or litter size (Supplemental Fig 1). Repeated measures ANOVAs indicated significant strain differences in female [strain $\times$ day interaction, $F(6,72)=6.84$, $p<0.0001$ ], but not male mice. Post-hoc comparisons showed that, in the females, C58/J pups weighed more than C57BL/6J pups on PND 3, but showed decreased weights by PNDs 16/17. The two strains did not differ at any other PND.

The litter size was also recorded on PND 1 and on every PND in which the pups were weighed (Supplemental Fig 1). The sex ratio of the litters on PND 3 did not differ across strains, with an average of $3.4(\mathrm{SEM}=0.6)$ males to $2.4(\mathrm{SEM}=0.6)$ females per litter in the $\mathrm{C} 57 \mathrm{BL} / 6 \mathrm{~J}$ group, and 2.9 (SEM=0.5) males to 1.8 (SEM=0.4) females in the $\mathrm{C} 58 / \mathrm{J}$ group. The two strains differed in litter size only on PND $1[\mathrm{~F}(1,20)=4.67 ; \mathrm{p}=0.0429]$ with $\mathrm{C} 57 \mathrm{BL} / 6 \mathrm{~J}$ litters being significantly larger. Additionally, the percentage of pups huddling together in the home-cage nest did not differ on any PND (data not shown).

\subsection{Neonatal Motor Screen and Activity}

3.2.1. PND 6-Data from PND 6 were analyzed for effects of strain and sex, in order to determine if significant differences could be detected within the first week of the postnatal period. The results showed that the $\mathrm{C} 58 / \mathrm{J}$ pups were hyperactive in the small open field, in comparison to the C57BL/6J pups, for measures of locomotion [square crossings; main effect of strain, $\mathrm{F}(1,29)=38.62, \mathrm{p}<0.0001$ ] and number of pivots [main effect of strain, $\mathrm{F}(1,29)=27.22$, $\mathrm{p}<0.0001]$. As shown in Table 2, the significant strain differences were observed in both the male and female groups [within-sex post-hoc comparisons, $\mathrm{p}<0.05]$. C58/J female mouse pups also righted more quickly than C57BL/6J females [main effect of strain, $\mathrm{F}(1,29)=8.83$, $\mathrm{p}=0.0059]$. A significant main effect of sex was observed for only one measure, negative geotaxis $[\mathrm{F}(1,29)=5.99, \mathrm{p}=0.0207]$. At this early time point, there were no strain differences in negative geotaxis, and virtually no rearing responses in the mouse pups.

3.2.2. PNDs 8 and 10 -In the second week of the neonatal period, the $\mathrm{C} 58 / \mathrm{J}$ mice continued to demonstrate hyperactivity in the small open field and faster righting times (Table 2). The $\mathrm{C} 58 / \mathrm{J}$ pups also turned more quickly in the negative geotaxis assay. Repeated measures ANOVAs indicated significant main effects of strain, but not sex or age, for measures of negative geotaxis $[\mathrm{F}(1,27)=5.62, \mathrm{p}=0.0251]$, righting $[\mathrm{F}(1,27)=11.44, \mathrm{p}=0.0022]$, and pivots $[F(1,27)=25.75, p<0.0001]$. A different pattern of strain differences was observed for the measure of square crossings during the open-field test [main effect of strain, $\mathrm{F}=27.32$, $\mathrm{p}<0.0001$; and 3-way interaction between strain, sex, and age, $\mathrm{F}(1,127)=7.89, \mathrm{p}=0.0091]$. Higher numbers of square crossings were found in the male C58/J mice on PND 8, and in both male and female C58/J mice on PND 10 [within-sex post-hoc comparisons, $\mathrm{p}<0.05$ ].

Only 5 rearing responses were observed on PND 8, all in the C58/J pups. On PND 10, the number of rearing responses had increased to a total of 47 in the $\mathrm{C} 58 / \mathrm{J}$ group, versus 2 responses in C57BL/6J pups.

\subsection{Open-field test on PNDs $16 / 17$ and $21 / 22$}

Overt strain differences in activity and exploration were clearly apparent later in the neonatal period (PNDs 16/17) and at the point of weaning (PNDs 20/21) (Table 3). The C58/J mice traveled markedly greater distance than the C57BL/6J mice during each 10-minute test (overall repeated measures ANOVA; main effect of strain, $F(1,28)=83.77, \mathrm{p}<0.0001]$ and made 
significantly more rearing responses [main effect of strain, $F(1,28)=93.23, p<0.0001$ ]. The most remarkable finding was that repetitive jumping responses emerged in C58/J, but not $\mathrm{C} 57 \mathrm{BL} / 6 \mathrm{~J}$, during this period [main effect of strain, $\mathrm{F}(1,28)=51.42$, $\mathrm{p}<0.0001$ ]. The $\mathrm{C} 58 / \mathrm{J}$ mice also had increased grooming time, dependent on age [main effect of strain, $\mathrm{F}(1,28)=6.48$, $\mathrm{p}=0.0167]$. For each measure, the overall repeated measures ANOVA found a significant interaction between strain and age [p values $<0.0005]$. However, none of the analyses for activity revealed significant main effects or interactions with sex, indicating that both male and female C58/J mice had similar abnormal behavioral profiles.

The open-field test can also be used to evaluate patterns of exploration. The C58/J mouse pups spent, in general, more time in the center region of the open field than the C57BL/6J pups [main effect of strain, $\mathrm{F}(1,28)=10.05, \mathrm{p}=0.0037$; non-significant effects of age and sex]. C58/ $\mathrm{J}$ mice also spent less time in the four corner regions of the open field, dependent on both age and sex [main effect of strain, $\mathrm{F}(1,28)=92.48, \mathrm{p}<0.0001$, and strain $\times$ age $\times$ sex interaction, $\mathrm{F}$ $(1,28)=5.05, \mathrm{p}=0.0328]$. Overall, the $\mathrm{C} 58 / \mathrm{J}$ mice did not demonstrate the same strong preference for the relatively enclosed corner areas observed in the C57BL/6J pups.

\subsection{Maternal behavior}

We assessed maternal be havior during the period of re-introduction of the pups to the dam following neonatal testing. Separate analyses were conducted for the earlier time points (PNDs $3-10$ ), when the pups were relatively inactive, and the later time points (PNDs 13-20/21), when the pups were showing forward locomotion. Overall, dams from both strains demonstrated low rates of huddling with or nursing the pups, perhaps because of the novelty of the new housing cage and laboratory environment. There were no strain differences in the amount of time dams spent in close proximity to at least one pup (Fig. 1), although the repeated measures ANOVA approached significance during the first days of testing [main effect of strain, $F(1,15)=4.22$; $\mathrm{p}=0.0579]$. However, clear differences were seen in repetitive cage-lid back-flipping, which was virtually never observed in the $\mathrm{C} 57 \mathrm{BL} / 6 \mathrm{~J}$ dams [main effect of strain, earlier measures, $\mathrm{F}$ $(1,15)=12.52 ; \mathrm{p}=0.003$; later measures, $\mathrm{F}(1,15)=52.68 ; \mathrm{p}<0.0001$ and strain $\times$ day interaction, $\mathrm{F}(2,30)=5.17 ; \mathrm{p}=0.0118]$. C58/J dams showed higher levels of self-grooming than the C57BL/ $6 \mathrm{~J}$ dams on almost every day of testing [main effect of strain, earlier measures, $\mathrm{F}(1,15)=38.23$; $\mathrm{p}<0.0001$; later measures, $\mathrm{F}(1,15)=4.86 ; \mathrm{p}=0.0435$; and strain $\times$ day interaction, earlier measures, $F(3,45)=2.85 ; p=0.0477$, later measures, $F(2,30)=3.48 ; p=0.0438]$. Interestingly, the $\mathrm{C} 58 / \mathrm{J}$ dams had a significantly lower frequency of digging behavior, in comparison to the $\mathrm{C} 57 \mathrm{BL} / 6 \mathrm{~J}$ controls [main effect of strain, earlier measures, $\mathrm{F}(1,15)=26.32 ; \mathrm{p}<0.0001$; later measures, $\mathrm{F}(1,15)=4.85 ; \mathrm{p}=0.0437$; and strain $\times$ day interaction, earlier measures, $\mathrm{F}(3,45)=$ 3.36; $\mathrm{p}=0.0267]$.

Pup behavior was measured concurrently with maternal behavior. There were almost no behaviors other than huddling with other pups across the earlier days of testing (data not shown). By PND 13, the C58/J pups were venturing from the pup huddle at a significantly higher frequency than the C57BL/6J pups [post-hoc test following main effect of strain, $\mathrm{F}(1,12)$ $=5.47 ; \mathrm{p}=0.0375]$ (Fig. 2). The emergence of repetitive jumping and upright scrabbling in the novel housing cage was observed in the C58/J pups, but not the C57BL/6J litters, by PND $20 / 21$, although significant strain differences were only found for the scrabbling measure [main effect of strain, $\mathrm{F}(1,15)=11.02 ; \mathrm{p}=0.0047$, strain $\times$ day interaction, $\mathrm{F}(2,30)=6.29 ; \mathrm{p}=0.0052]$. These results show that indices of repetitive behavior can be seen in C58/J pups, even in the presence of the dam and littermates. Other measures, including self-grooming (Fig. 2) and rearing (data not shown), were similar in the two strains. 


\subsection{Repetitive behavior in adolescent and young adult mice}

A second cohort of C57BL/6J and C58/J mice were tested in assays for olfactory discrimination, social approach, and social transmission of food preference. As presented in Table 4 , from $69 \%$ to $88 \%$ of the $\mathrm{C} 58 / \mathrm{J}$ mice demonstrated jumping during these tasks, confirming the previous report of repetitive behavior in C58/J mice [36]. Significant differences in jumping between $\mathrm{C} 58 / \mathrm{J}$ and C57BL/6 J mice were observed in both male and female groups in each of the assays $\left[\chi^{2}<0.05\right]$. Examination of the data from the social choice test indicated that $33 \%$ of the $\mathrm{C} 58 / \mathrm{J}$ group jumped more than 30 times during the procedure, with $5 \mathrm{C} 58 / \mathrm{J}$ mice exhibiting 100 jumps or more in the social choice test. This strain also had more bouts of self-grooming during the choice test. However, not all behaviors were increased in C58/J. During the olfactory discrimination assay, very few mice from either strain reacted to the presentation of the different scents by biting or climbing on the cotton swab. In addition, the majority of C57BL/6J mice, but less than half of the C58/J mice, demonstrated digging in the cage bedding. This pattern of higher self-grooming, but reduced digging, in C58/J was similar to the results from the maternal behavior test shown in Fig. 1.

\subsection{Olfactory habituation/dishabituation}

No significant effects of strain or sex were observed for time spent sniffing the different types of olfactory stimuli (Mann-Whitney $U$ tests; Fig. 3). Overall, mice from both strains had a clear preference for the initial presentation of the social stimulus (odor from a soiled home cage of same-sex mice), in comparison to water or the non-social stimuli (almond or banana scent). Similar patterns of habituation w ere observed in the C58/J and C57BL/6J mice, suggesting that the two strains had comparable ability to discriminate between unfamiliar and familiar olfactory stimuli.

\subsection{Three-chambered social choice test}

3.7.1. Test for sociability-Only the C57BL/6J mice showed a preference for spending more time with the stranger mouse, versus the empty cage [within-strain post-hoc tests following significant effect of chamber side, $F(1,69)=19.22$, $p<0.0001]$. Time in the center chamber was not included in the analyses. Overall repeated measures ANOVAs revealed significant effects of both strain and sex on time spent in each side [main effect of strain, $F$ $(1,69)=4.74, p=0.0329$; strain $\times$ sex interaction, $F(1,69)=4.56, p=0.0364]$ and time spent sniffing the wire cages [main effect of strain, $F(1,67)=19.23$, $\mathrm{p}<0.0001$; strain $\times$ chamber side interaction, $\mathrm{F}(1,67)=4.99$, $\mathrm{p}=0.0289$; sex $\times$ side interaction, $\mathrm{F}(1,67)=4.22$, $\mathrm{p}=0.044]$. Separate analyses of the data from each sex indicated that significant differences between the strains were only present in the male groups (Fig. 4). There were no effects of strain or sex on number of entries (Supplemental Fig. 2).

During the sociability test, the C58/J male mice spent significantly less time than the C57BL/ $6 \mathrm{~J}$ male mice in the chamber with the stranger mouse [post-hoc test following significant main effect of strain, $\mathrm{F}(1,40)=9.57$, $\mathrm{p}=0.0036$; and $\operatorname{strain} \times$ side interaction, $\mathrm{F}(1,40)=6.74, \mathrm{p}=0.0131]$. The C58/J male mice also directed significantly less sniffing than the C57BL/6J males toward the stranger mouse and toward the novel empty cage [post-hoc tests following significant main effect of strain, $\mathrm{F}(1,39)=23.66$, $\mathrm{p}<0.0001$; and strain $\times$ side interaction, $\mathrm{F}(1,39)=8.58$, $\mathrm{p}=0.0057]$. As observed in previous strain comparisons [36], all groups demonstrated a significant preference for sniffing at the cage containing stranger 1 in the sociability assay [within-strain post-hoc tests following significant effect of side, $F(1,67)=185.57, \mathrm{p}<0.0001$ ].

3.7.2. Preference for social novelty-An overall repeated measures ANOVA did not reveal any significant effects of strain on time spent in proximity to stranger 1 and stranger 2, although an interaction between sex and side was found $[\mathrm{F}(1,68)=7.42, \mathrm{p}=0.0082]$. Again, time spent in the center chamber was not included in the analyses. All groups, except the female 
C58/J mice, demonstrated a significant preference for the newly-introduced stranger 2 [posthoc tests following a significant effect of side, $F(1,68)=10.65$, $p=0.0017]$ (Fig. 4). However, highly significant effects of strain were found in the male groups for the measure of sniffing during the test for social novelty [main effect of strain, $\mathrm{F}(1,40)=23.56$, $\mathrm{p}<0.0001$; and strain $\times$ side interaction, $\mathrm{F}(1,40)=11.76, \mathrm{p}=0.0014]$. Post-hoc tests indicated that the male $\mathrm{C} 58 / \mathrm{J}$ mice directed significantly less sniffing than the C57BL/6J mice towards the two stranger mice. These strain differences were not observed in the female mice.

\subsection{Social transmission of food preference}

In the STFP assay, male C57BL/6J mice showed significantly greater affinity for the cued food in comparison to the non-cued food as measured by amount of food consumed $[\mathrm{F}(1,30)=15.21$; $\mathrm{p}=0.0005]$ and by the number of feeding bouts at each $\operatorname{jar}[\mathrm{F}(1,30)=7.85 ; \mathrm{p}=0.0088]$. In contrast, the $\mathrm{C} 58 / \mathrm{J}$ male mice showed no preference for the cued food by either measure (Fig. 5). In addition, C58/J male mice had significantly fewer feeding bouts at the target food jar, in comparison to $\mathrm{C} 57 \mathrm{BL} / 6 \mathrm{~J}$ males $[\mathrm{F}(1,38)=11.44 ; \mathrm{p}=0.0017]$. A food preference was calculated for each strain (amount of target food consumed / total amount of food consumed) and the C57BL/6J males had a significantly higher preference than the C58/J males for the target food $[\mathrm{F}(1,38)=8.23 ; \mathrm{p}=0.0067]$.

In contrast to the male mice, the female $\mathrm{C} 57 \mathrm{BL} / 6 \mathrm{~J}$ and $\mathrm{C} 58 / \mathrm{J}$ mice did not differ in their affinity for the target food as measured in the STFP assay (Fig. 5). The C57BL/6J females showed a marginal preference for the target food as measured by the amount of food consumed $[F(1,24)$ $=3.58 ; \mathrm{p}=0.0705]$, but a stronger preference when measured by eating bouts $[\mathrm{F}(1,24)=4.27$; $\mathrm{p}=0.0497]$. The $\mathrm{C} 58 / \mathrm{J}$ female mice showed a similar pattern, with non-significant preference for the target food as measured by the amount of food consumed [ $\mathrm{F}(1,30)=2.86 ; \mathrm{p}=0.1011]$, but a strong preference when measured by eating bouts $[F(1,22)=9.50 ; p=0.0054]$. No strain differences were observed for food preference scores.

\section{Discussion}

The present studies confirmed and extended previous findings of impaired social behavior and abnormal repetitive responses in C58/J mice, in comparison to C57BL/6J [37]. Significant strain differences in social behavior were found in the male, but not the female, groups. However, both male and female adult C58/J mice consistently showed distinctive motor stereotypy, including repeated "jack-hammer" jumping, repeated back flipping, and upright scrabbling. Repetitive behaviors were present in most C58/J mice tested in these experiments, but were essentially absent in the control C57BL/6J mice. The stereotyped behaviors were observed in social situations (three-chambered social approach, STFP), non-social situations (olfactory habituation/dishabituation), and during the maternal behavior assays. Remarkably, male and female $\mathrm{C} 58 / \mathrm{J}$ mouse pups had higher rates of pivoting and locomotor activity than the C57BL/6J pups from PND 6 onward, indicating that unusual repetitive behavior emerges early during neonatal development in C58/J mice and persists into adulthood.

In autism, specific forms and severity of repetitive behavior can vary, dependent upon age [12]. Our findings demonstrate how stage of maturation is an important determinant in the particular topography of repetitive behavior in C58/J mice. For example, during the neonatal screen, rearing responses were not observed in the first week of life, and only occasionally seen at PND 10. This time course is similar to the findings of Brunner et al. [5], who reported very low levels of rearing (or "rises") in mice at PND 6 and 9, with more responses observed on PNDs 12 and 15. In the present study, both male and female C58/J mice had significantly greater rearing responses than the C57BL/6J pups by PND 16/17. In fact, rearing responses were almost zero in the female C57BL/6J group at PND 16/17, suggesting that the C58/J mice had an earlier emergence of this behavior. By PND 20/21, the enhanced rearing was even more 
marked in the C58/J group. It is possible that these enhanced rearing responses during the neonatal period were precursors to the aberrant, stereotyped jumping and upright scrabbling observed in juvenile and young adult $\mathrm{C} 58 / \mathrm{J}$ mice. One study has reported an association between rearing responses and persistent jumping in adult mice characterized by repetitive behavior [47]. Tracing the ontogeny of rearing responses may provide information on the emergence of behavior that is predictive of abnormal stereotypy at later stages of development.

We also found that environmental parameters played a role in repetitive behavior topography. The high level of back flipping so distinctive in the C58/J dams and during the olfactory habituation/dishabituation task was dependent on an environmental setting that included a metal-bar cage lid, and was not observed in more open test settings, such as the three-chambered social test box. It is also notable that the C58/J mice had selective decreases, as well as increases, in some types of behavior. In multiple assays, the C58/J mice spent less time digging in their bedding than the $\mathrm{C} 57 \mathrm{BL} / 6 \mathrm{~J}$ controls. Male $\mathrm{C} 58 / \mathrm{J}$ mice also showed less sniffing directed to social and non-social objects in the three-chambered choice task. These deficiencies may be reflective of the C58/J mice having less time allocated for such behaviors, since motor stereotypies are so prevalent in this strain. High levels of anxiety can depress exploratory behaviors in mice [9]; however, the C58/J mice did not demonstrate an anxiety-like phenotype in the open field testing. Alternately, the deficiencies may suggest reduced exploration, relevant to similar deficits in exploration, lack of curiosity about environmental stimuli, and other forms of restricted behavior characteristic of autism (e.g. [42]).

Deer mice (Peromyscus maniculatus) display motor stereotypies very similar to C58/J mice, including repeated jumping and back flipping [27,43,44]. Incidence of these stereotypies can be greatly reduced by housing deer mice in an enriched environment after weaning $[43,44]$. Studies on striatal neurochemistry have indicated that abnormal cortical-basal ganglia pathways contribute to the development of repetitive be haviors in deer mice [45,47]. This hypothesis is supported by the fact that dopamine and NMDA receptor antagonists attenuate the stereotypies $[27,46]$. Striatal dysfunction may also underlie symptoms in human disorders characterized by repetitive responses. In autistic subjects, alterations in caudate volume have been found to significantly correlate with levels of repetitive behavior [17,54]. Similarly, caudate volume in fragile $\times$ subjects had significant correlation with a measure of stereotypy, as well as a general score for autism-like behavior [16]. Altered striatal neurotransmission has been found in Tourette syndrome and obsessive-compulsive disorder, which are also associated with abnormal repetitive behavior $[41,58]$.

The present study confirmed that male C58/J mice demonstrate a significant decrease in sociability in a three-chambered choice task, measured as a preference for spending time in proximity to an unfamiliar mouse versus a novel object [37]. The social deficits seen in male C58/J mice were also observed in the STFP assay. However, in contrast to abnormal repetitive behaviors, which were found in both sexes of $\mathrm{C} 58 / \mathrm{J}$ mice, significant strain differences in social behavior were only detected in the male mice. The female mice from both strains had generally lower levels of sociability and transmission of food preference, in comparison to the male groups, making the detection of significant impairment in the C58/J females difficult.

An important issue with the interpretation of the social test results is whether the lower social approach in the male C58/J mice could be attributed to general hyperactivity. Previous work from our laboratory and other researchers has not found higher activity in adolescent or adult mice from the $\mathrm{C} 58 / \mathrm{J}$ strain, versus C57BL/6J, in an open field [1,37]. In the present study, the $\mathrm{C} 58 / \mathrm{J}$ and $\mathrm{C} 57 \mathrm{BL} / 6 \mathrm{~J}$ mice had similar numbers of entries during every component of the social approach test, providing evidence that the two strains explored the three-chambered box to a comparable degree. Significant strain differences in social approach were not found in the female groups, despite the observation of jumping in most of the C58/J female mice. Further, 
in the social novelty test, the $\mathrm{C} 58 / \mathrm{J}$ and $\mathrm{C} 57 \mathrm{BL} / 6 \mathrm{~J}$ males showed very similar preference for spending time in the side containing the newly-introduced stranger mouse. Overall, these results suggest that other factors, besides overt hyperactivity, may play a role in altered social behavior. It is notable that we did find markedly increased locomotion in the separate set of male and female C58/J mice tested during the neonatal period. Given the repeated disruption of dams and litters for the postnatal testing, this early locomotor hyperactivity could have been driven by both stage of development and repeated exposure to stress. The effect of the disruption on the dams may have made the detection of strain differences in maternal responses directed toward the pups, another index of social behavior, more difficult.

Decreased olfactory ability could also be a factor in reduced social approach. Earlier studies on the C58/J mouse measured olfactory ability in this strain; however, these studies did not measure social odor discrimination. In mice, olfactory cues are detected by both the main olfactory system and the accessory olfactory system $[3,49]$. The accessory olfactory bulb processes non-volatile pheromones whereas the main olfactory bulb primarily processes volatile odorants and is responsive to social cues present in urine [20,30,49,53]. It is likely that both systems play a role in social behavior $[18,30,52]$ and it is possible for a mouse to have selective impairment in only one system [21], resulting in a strain that cannot differentiate among socially relevant odors despite being able to smell other objects (such as food). The results from the olfactory habituation/dishabituation procedure indicate that both male and female C58/J mice have the ability to discriminate both social and non-social odors. The social deficits seen with the $\mathrm{C} 58 / \mathrm{J}$ strain, therefore, are most likely not related to olfactory ability. In fact, the C58/J male mice had a preference for the social odors comparable to the C57BL/6J male mice in this assay, in contrast to their reduced sniffing behavior in both the STFP assay and the three-chambered social approach test. The results suggest that C58/J have selective deficits in sustained social interest directed toward another mouse, versus attention directed toward a social olfactory cue.

Other inbred mouse strains show evidence of social deficits similar to those reported here. $\mathrm{BALB} / \mathrm{c}$ mice show low levels of sociability in a variety of testing paradigms and these deficits appear to correlate with corpus callosum underdevelopment $[4,13]$. Another inbred mouse strain, BTBR T+t/fJ, also shows reduced sociability in the three-chamber social approach assay and STFP and has an absence of the corpus callosum $[2,34,36,56]$. However, recent evidence from lesion studies in C57BL/6J mice has failed to confirm that social approach is dependent upon intact callosal function [61].

Overall, the C58/J strain may provide a model for symptoms in neurodevelopmental disorders, including deficits in social approach and communication, and restricted, repetitive behavior. The abnormal phenotype arises early in development and can be observed across different measures and test settings. Altered behavior and social impairment are not associated with overt deficiencies in olfactory ability or maternal care. One key advantage of using an inbred strain as a disease model is the ability to study complex genetic factors and processes, such as those proposed for autism [31,32]. In fact, quantitative trait loci associated with open-field behavior have been identified in progeny from C58/J and C57BL/6J crossings [1]. Further studies in the C58/J model may help elucidate neural circuitry and heritable components for stereotypy and social impairment relevant to human clinical disorders.

\section{Supplementary Material}

Refer to Web version on PubMed Central for supplementary material. 


\section{Acknowledgments}

The authors would like to thank Randal Nonneman, Joe Piven and Steve Reznick for their valuable assistance and insight throughout this project. This work was supported by NIMH grants R21 MH084132 and R01 MH73402, and NICHD grants T32 HD40127 and P30 HD03110 and the National Institute of Mental Health Intramural Research Program.

\section{References}

1. Bailey JS, Grabowski-Boase L, Steffy BM, Wiltshire T, Churchill GA, Tarantino LM. Identification of QTL for locomotor activation and anxiety using closely-related inbred strains. Genes Brain Behav 2008;7:761-769. [PubMed: 19130624]

2. Bolivar VJ, Walters SR, Phoenix JL. Assessing autism-like behavior in mice: variations in social interactions among inbred strains. Behav Brain Res 2007;176:21-26. [PubMed: 17097158]

3. Brennan PA, Kendrick KM. Mammalian social odours: attraction and individual recognition. Philos Trans R Soc Lond B Biol Sci 2006;361:2061-2078. [PubMed: 17118924]

4. Brodkin ES. BALB/c mice: low sociability and other phenotypes that may be relevant to autism. Behav Brain Res 2007;176:53-65. [PubMed: 16890300]

5. Brunner D, Buhot MC, Hen R, Hofer M. Anxiety, motor activation, and maternal-infant interactions in 5HT $1 \mathrm{~B}$ knockout mice. Behav Neurosci 1999;113:587-601. [PubMed: 10443785]

6. Bunsey M, Eichenbaum H. Selective damage to the hippocampal region blocks long-term retention of a natural and non-spatial stimulus-stimulus association. Hippocampus 1995;5:546-556. [PubMed: 8646281]

7. Castelli F, Frith C, Happe F, Frith U. Autism, Asperger syndrome and brain mechanisms for the attribution of mental states to animated shapes. Brain 2002;125:1839-1849. [PubMed: 12135974]

8. Cheh MA, Millonig JH, Roselli LM, Ming X, Jacobsen E, Kamdar S, Wagner GC. En2 knockout mice display neurobehavioral and neurochemical alterations relevant to autism spectrum disorder. Brain Res 2006;1116:166-176. [PubMed: 16935268]

9. Crawley JN. Exploratory behavior models of anxiety in mice. Neurosci Biobeh Rev 1985;9:37-44.

10. Crawley JN, Chen T, Puri A, Washburn R, Sullivan TL, Hill JM, Young NB, Nadler JJ, Moy SS, Young LJ, Caldwell HK, Young WS. Social approach behaviors in oxytocin knockout mice: comparison of two independent lines tested in different laboratory environments. Neuropeptides 2007;41:145-163. [PubMed: 17420046]

11. Del Punta K, Leinders-Zufall T, Rodriguez I, Jukam D, Wysocki CJ, Ogawa S, Zufall F, Mombaerts $\mathrm{P}$. Deficient pheromone responses in mice lacking a cluster of vomeronasal receptor genes. Nature 2002;419:70-74. [PubMed: 12214233]

12. Esbensen AJ, Seltzer MM, Lam KSL, Bodfish JW. Age-related differences in restricted repetitive behaviors in autism spectrum disorders. J Autism Dev Disord 2009;39:57-66. [PubMed: 18566881]

13. Fairless AH, Dow HC, Toledo MM, Malkus KA, Edelmann M, Li H, Talbot K, Arnold SE, Abel T, Brodkin ES. Low sociability is associated with reduced size of the corpus callosum in the BALB/cJ inbred mouse strain. Brain Res 2008;1230:211-217. [PubMed: 18662677]

14. Fox, RR.; Witham, BA., editors. Handbook on genetically standardized JAX mice. Bar Harbor, ME: The Jackson Laboratory; 1997. p. XX

15. Galef BG Jr, Kennett DJ. Different mechanisms for social transmission of food preference in rat pups of different ages. Dev Psychobiol 1987;20:209-215. [PubMed: 3582781]

16. Gothelf D, Furfaro JA, Hoeft F, Eckert MA, Hall SS, O’Hara R, Erba HW, Ringel J, Hayashi KM, Patnaik S, Golianu B, Kraemer HC, Thompson PM, Piven J, Reiss AL. Neuroanatomy of fragile $\times$ syndrome is associated with aberrant behavior and the fragile $\times$ mental retardation protein (FMRP). Ann Neurosci 2008;63:40-51.

17. Hollander E, Anagnostu E, Chaplin W, Esposito K, Haznedar MM, Licalzi E, Wasserman S, Soorya L, Buchsbaum M. Striatal volume on magnetic resonance imaging and repetitive behaviors in autism. Biol Psychiatry 2005;58:226-232. [PubMed: 15939406]

18. Jakupovic J, Kang N, Baum MJ. Effect of bilateral accessory olfactory bulb lesions on volatile urinary odor discrimination and investigation as well as mating behavior in male mice. Physiol Behav 2008;93:467-473. [PubMed: 17991495] 
19. Kennedy DP, Courchesne E. The intrinsic functional organization of the brain is altered in autism. Neuroimage 2008;39:1877-1885. [PubMed: 18083565]

20. Keverne EB. Importance of olfactory and vomernasal systems for male sexual function. Physiol Behav 2004;83:177-187. [PubMed: 15488538]

21. Kimchi T, Xu J, Dulac C. A functional circuit underlying male sexual behaviour in the female mouse brain. Nature 2007;448:1009-1014. [PubMed: 17676034]

22. Kleinhans NM, Richards T, Sterling L, Stegbauer KC, Mahurin R, Johnson LC, Greenson J, Dawson G, Aylward E. Abnormal functional connectivity in autism spectrum disorders during face processing. Brain 2008;131:1000-1012. [PubMed: 18234695]

23. Kogan JH, Frankland PW, Blendy JA, Coblentz J, Marowitz Z, Schutz G, Silva AJ. Spaced training induces normal long-term memory in CREB mutant mice. Curr Biol 1997;7:1-11. [PubMed: 8999994]

24. Koshino H, Kana RK, Keller TA, Cherkassky VL, Minshew NJ, Just MA. fMRI investigation of working memory for faces in autism: visual coding and underconnectivity with frontal areas. Cereb Cortex 2008;18:289-300. [PubMed: 17517680]

25. Lainhart JE, Piven J. Diagnosis, treatment, and neurobiology of autism in children. Curr Opin Pediatr 1995;7:392-400. [PubMed: 7581642]

26. Lee AW, Brown RE. Comparison of medial preoptic, amygdala, and nucleus accumbens lesions on parental behavior in California mice (Peromyscus californicus). Physiol Behav 2007;92:617-628. [PubMed: 17610916]

27. Lewis MH, Tanimura Y, Lee LW, Bodfish JW. Animal models of restricted repetitive behavior in autism. Behav Brain Res 2007;176:66-74. [PubMed: 16997392]

28. Leypold BG, Yu CR, Leinders-Zufall T, Kim MM, Zufall F, Axel R. Altered sexual and social behaviors in trp2 mutant mice. Proc Natl Acad Sci USA 2002;99:6376-6381. [PubMed: 11972034]

29. Liebenauer LL, Slotnick BM. Social or ganization and aggression in a group of olfactory bulbectomized male mice. Physiol Behav 1996;60:403-409. [PubMed: 8840898]

30. Lin DY, Zhang S-Z, Block E, Katz LC. Encoding social signals in the mouse main olfactory bulb. Nature 2005;434:470-477. [PubMed: 15724148]

31. Lord C, Cook EH, Leventhal BL, Amaral DG. Autism spectrum disorders. Neuron 2000;28:355-363. [PubMed: 11144346]

32. Losh M, Sullivan PF, Trembath D, Piven J. Current developments in the genetics of autism: from phenome to genome. J Neuropathol Exp Neurol 2008;67:829-837. [PubMed: 18716561]

33. Luo AH, Cannon EH, Wekesa KS, Lyman RF, Vandenbergh JG, Anholt RR. Impaired olfactory behavior in mice deficient in the alpha subunit of G(o). Brain Res 2002;941:62-71. [PubMed: 12031548]

34. McFarlane HG, Kusek GK, Yang M, Phoenix JL, Bolivar VJ, Crawley JN. Autism-like behavioral phenotypes in BTBR T+tf/J mice. Genes Brain Behav 2008;7:152-163. [PubMed: 17559418]

35. Moy SS, Nadler JJ, Young NB, Nonneman RJ, Grossman AW, Murphy DL, D'Ercole AJ, Crawley JN, Magnuson TR, Lauder JM. Social Approach in Genetically-Engineered Mouse Lines Relevant to Autism. Genes Brain Behav 2009;8:129-142. [PubMed: 19016890]

36. Moy SS, Nadler JJ, Young NB, Perez A, Holloway LP, Barbaro RP, Barbaro JR, Wilson LM, Threadgill DW, Lauder JM, Magnuson TR, Crawley JN. Mouse behavioral tasks relevant to autism: phenotypes of 10 inbred strains. Behav Brain Res 2007;176:4-20. [PubMed: 16971002]

37. Moy SS, Nadler JJ, Young NB, Nonneman RJ, Segall SK, Andrade GM, Crawley JN, Magnuson TR. Social approach and repetitive behavior in eleven inbred mouse strains. Behav Brain Res 2008;191:118-129. [PubMed: 18440079]

38. Nadler JJ, Moy SS, Dold G, Trang D, Simmons N, Perez A, Young NB, Barbaro RP, Piven J, Magnuson TR, Crawley JN. Automated apparatus for quantification of social approach behaviors in mice. Genes Brain Behav 2004;3:303-314. [PubMed: 15344923]

39. Newschaffer CJ, Croen LA, Daniels J, Giarelli E, Grether JK, Levy SE, Mandell DS, Miller LA, Pinto-Martin J, Reaven J, Reynolds AM, Rice CA, Schendel D, Windham GC. The epidemiology of autism spectrum disorders. Annu Rev Public Health 2007;28:235-258. [PubMed: 17367287] 
40. Nicot A, Otto T, Brabet P, Dicicco-Bloom EM. Altered social behavior in pituitary adenylate cyclaseactivating polypeptide type I receptor-deficient mice. J Neurosci 2004;24:8786-8795. [PubMed: 15470144]

41. Perani D, Garibotto V, Gorini A, Moresco RM, Henin M, Panzacchi A, Matarrese M, Carpinelli A, Bellodi L, Fazio F. In vivo PET study of 5HT(2A) serotonin and $\mathrm{D}(2)$ dopamine dysfunction in drugnaïve obsessive-compulsive disorder. Neuroimage 2008;42:306-314. [PubMed: 18511303]

42. Pierce K, Courchesne E. Evidence for a cerebellar role in reduced exploration and stereotyped behavior in autism. Biol Psychiatry 2001;49:655-664. [PubMed: 11313033]

43. Powell SB, Newman HA, McDonald TA, Bugenhagen P, Lewis MH. Development of spontaneous stereotyped behavior in deer mice: effects of early and late exposure to a more complex environment. Dev Psychobiol 2000;37:100-108. [PubMed: 10954835]

44. Powell SB, Newman HA, Pendergast JF, Lewis MH. A rodent model of spontaneous stereotypy: initial characterization of developmental, environmental, and neurobiological factors. Physiol Behav 1999;66:355-363. [PubMed: 10336165]

45. Presti MF, Lewis MH. Striatal opioid peptide content in an animal model of spontaneous stereotypic behavior. Behav Brain Res 2005;157:363-368. [PubMed: 15639187]

46. Presti MF, Mikes HM, Lewis MH. Selective blockade of spontaneous motor stereotypy via intrastriatal pharmacological manipulation. Pharmacol Biochem Behav 2003;74:833-839. [PubMed: 12667897]

47. Presti MF, Watson CJ, Kennedy RT, Yang M, Lewis MH. Behavior-related alterations of striatal neurochemistry in a mouse model of stereotyped movement disorder. Pharm Biochem Behav 2004;77:501-507.

48. Randall PK, Randall JS. Mouse strain differences in apomorphine-induced behavior: an empirical and methodological study. Behav Neurosci 1986;100:85-92. [PubMed: 3954884]

49. Restrepo D, Arellano J, Oliva AM, Schaefer ML, Lin W. Emerging views of the distinct but related roles of the main and accessory olfactory systems in responsiveness to chemosensory signals in mice. Horm Behav 2004;46:247-256. [PubMed: 15325226]

50. Rustay NR, Wrenn CC, Kinney JW, Holmes A, Bailey KR, Sullivan TL, Harris AP, Long KC, Saavedra MC, Starosta G, Innerfield CE, Yang RJ, Dreiling JL, Crawley JN. Galanin impairs performance on learning and memory tasks: findings from galanin transgenic and GAL-R1 knockout mice. Neuropeptides 2005;39:239-243. [PubMed: 15944016]

51. Ryan BC, Young NB, Moy SS, Crawley JN. Olfactory cues are sufficient to elicit social approach behaviors but not social transmission of food preference in C57BL/6J mice. Behav Brain Res 2008;193:235-242. [PubMed: 18586054]

52. Schaefer ML, Yamazaki K, Osada K, Restrepo D, Beauchamp GK. Olfactory fingerprints for major histocompatibility complex determined body odors II: relationship among odor maps, genetics, odor composition, and behavior. J Neurosci 2002;22:9513-9521. [PubMed: 12417675]

53. Schaefer ML, Young DA, Restrepo D. Olfactory fingerprints for major histocompatibility complexdetermined body odors. J Neurosci 2001;21:2481-2487. [PubMed: 11264322]

54. Sears LL, Vest C, Mohamed S, Bailey J, Ranson BJ, Piven J. An MRI study of the basal ganglia in autism. Prog Neuropsychopharmacol Biol Psychiatry 1999;23:613-624. [PubMed: 10390720]

55. Valsecchi P, Galef BG Jr. Social influences on the food preference of house mice (Mus musculus). Int J Comp Psychol 1989;2:245-256.

56. Wahlsten D, Metten P, Crabbe JC. Survey of 21 inbred mouse strains in two laboratories reveals that $\mathrm{BTBR} \mathrm{T} / \mathrm{tf} / \mathrm{tf}$ has severely reduced hippocampal commisure and absent corpus callosum. Brain Res 2003;971:47-54. [PubMed: 12691836]

57. Wersinger SR, Caldwell HK, Martinez L, Gold P, Hu SB, Young WS 3rd. Vasopressin 1a receptor knockout mice have a subtle olfactory deficit but normal aggression. Genes Brain Behav 2007;6:540551. [PubMed: 17083331]

58. Wong DF, Brasic JR, Singer HS, Schretien DJ, Kuwabara H, Zhou Y, Nandi A, Maris MA, Alexander M, Ye W, Rousset O, Kumar A, Szabo Z, Gjedde A, Grace AA. Mechanisms of dopaminergic and serotonergic neurotransmission in Tourette syndrome: clues from an in vivo neurochemistry study with PET. Neuropsychopharmacology 2008;33:1239-1251. [PubMed: 17987065] 
59. Wrenn CC. Social transmission of food preference in mice. Curr Protocols Neurosci 2004:8.5G.18.5G.7.

60. Wrenn CC, Harris AP, Saavedra MC, Crawley JN. Social transmission of food preference in mice: methodology and application to galanin-overexpressing transgenic mice. Behav Neurosci 2003;117:21-31. [PubMed: 12619904]

61. Yang M, Clark AM, Crawley JN. Postnatal lesion evidence against a primary role for the corpus callosum in mouse sociability. Eur J Neurosci 2009;29:1663-1677. [PubMed: 19419429] 
Time Spent in Proximity to Pups

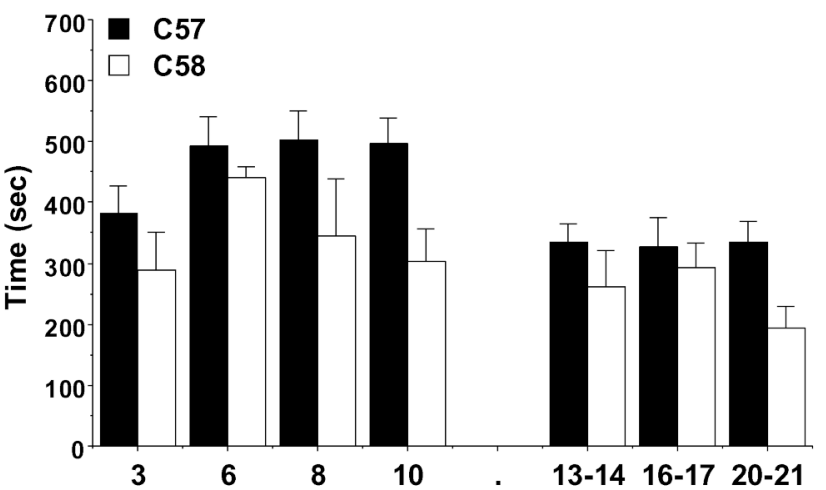

Self-Grooming Bouts

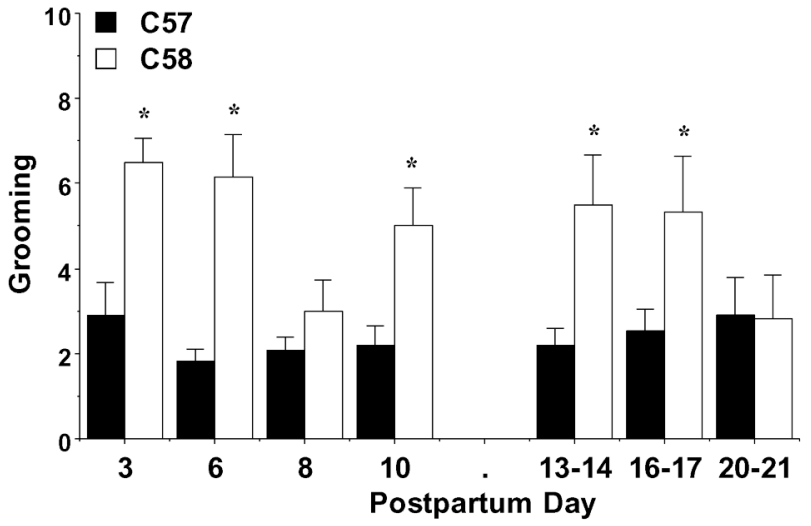

Back Flips

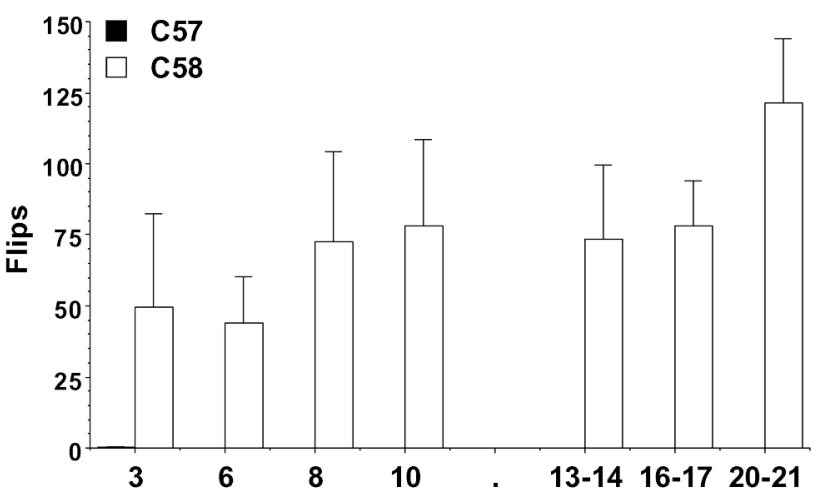

Digging Bouts

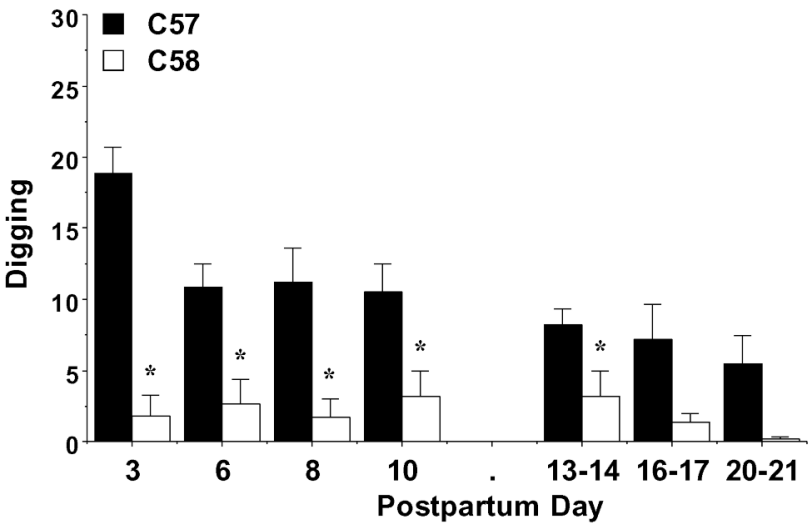

Fig 1. Maternal behavior in C57 and C58 dams

Measures were taken during a 15-min test in a clean cage containing the dam and litter. Data shown are mean + SEM for 11 C57 and 6 C58 dams. Post-hoc tests were not conducted for (B), due to zero scores for the C57 dams. * p<0.05. 

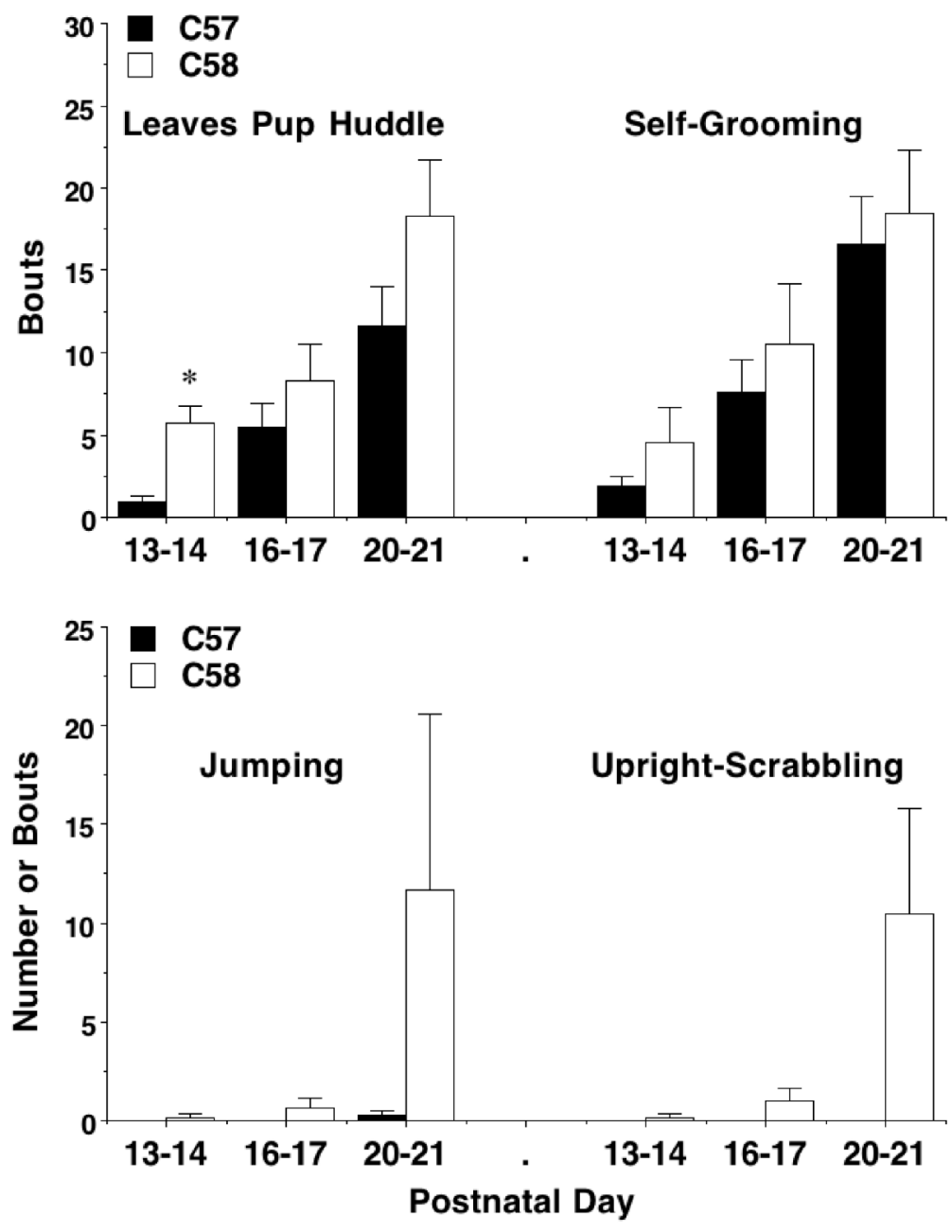

Fig 2. Pup responses during the maternal behavior test

Measures were taken during a 15-min test in a clean housing cage containing the dam and litter. Data shown are mean + SEM for 11 C57 and 6 C58 litters. Data are missing for one C57 litter and 2 C58 litters for the measure of "Leaves Pup Huddle." Post-hoc tests were not conducted for "Upright-Scrabbling", due to zero scores for the C57 pups. * $\mathrm{p}<0.05$. 

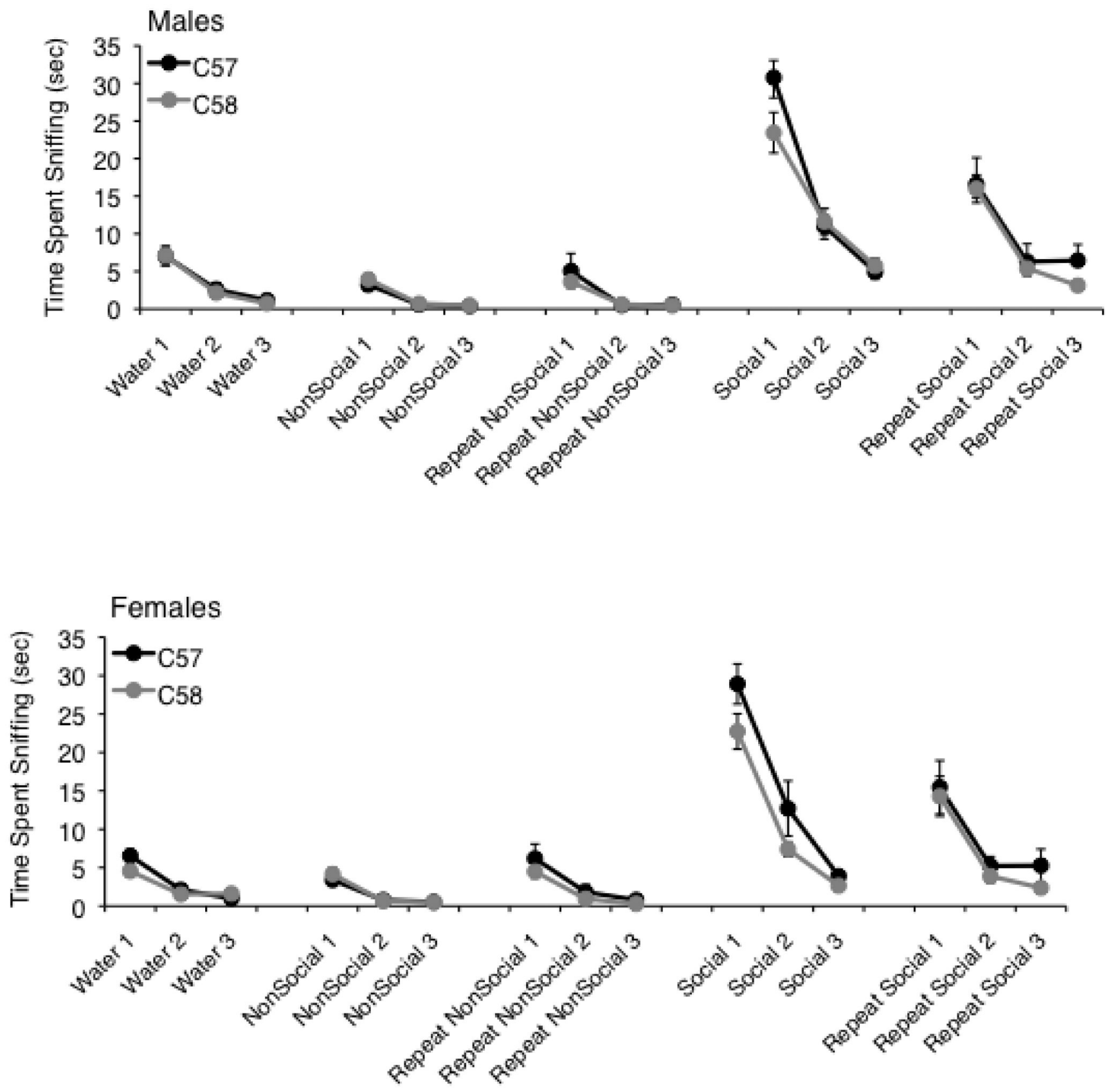

Fig 3. Time spent sniffing the cotton swab in the olfactory habituation/dishabituation assay No significant differences between the two strains were found for either sex. Data shown are mean \pm SEM. 
Sociability: Time in Each Side

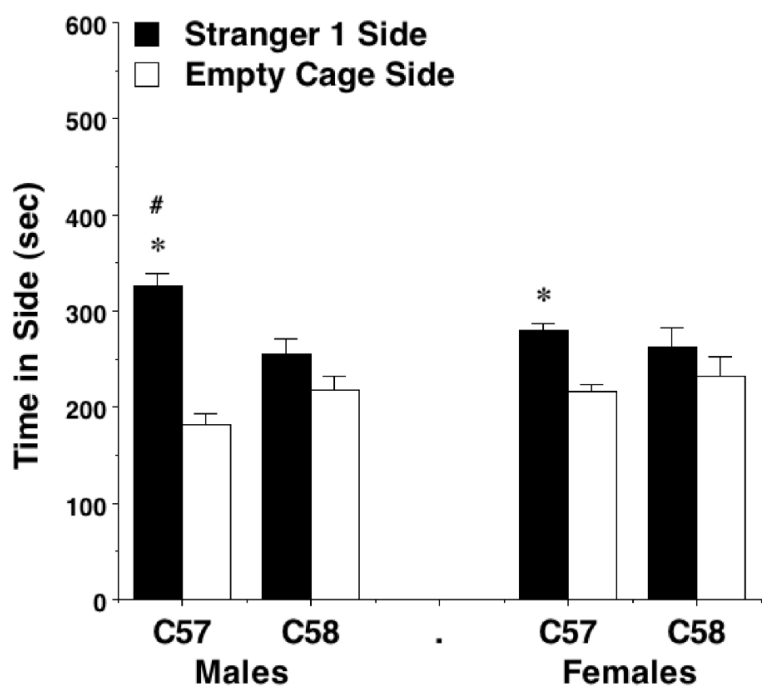

Social Novelty: Time in Each Side

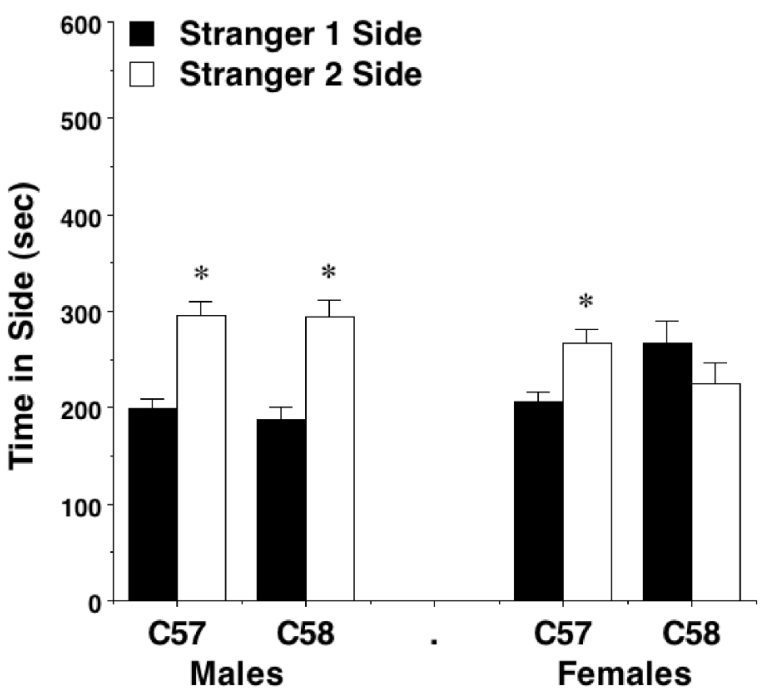

Sociability: Time Spent Sniffing Each Cage

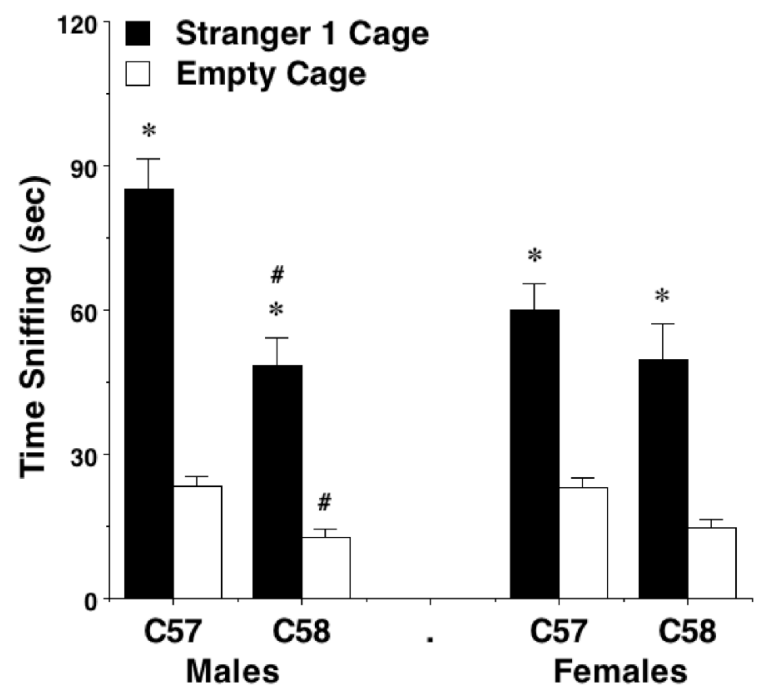

Social Novelty: Time Spent Sniffing Each Cage

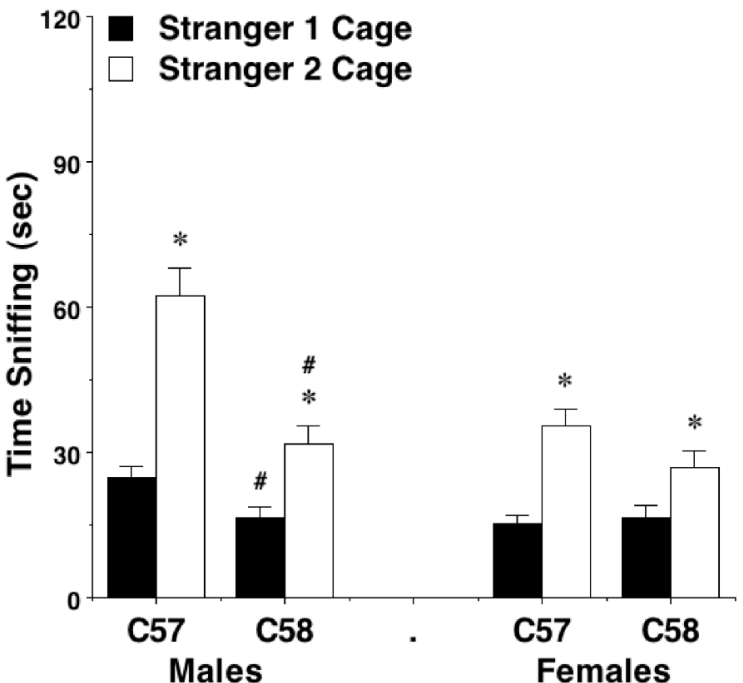

Fig 4. Social approach in a three-chambered choice task

Measures taken were time in each side and time spent sniffing each wire cage during tests for sociability (upper panels) and preference for social novelty (lower panels). Significant strain differences in social approach were only observed in the male groups (upper panels, lower right panel). Data shown are mean + SEM for each 10 -min test. \# $p<0.05$, across-strain comparison with same measure in same-sex mice. $* \mathrm{p}<0.05$, within-group comparison, stranger 1 side different from opposite side. 

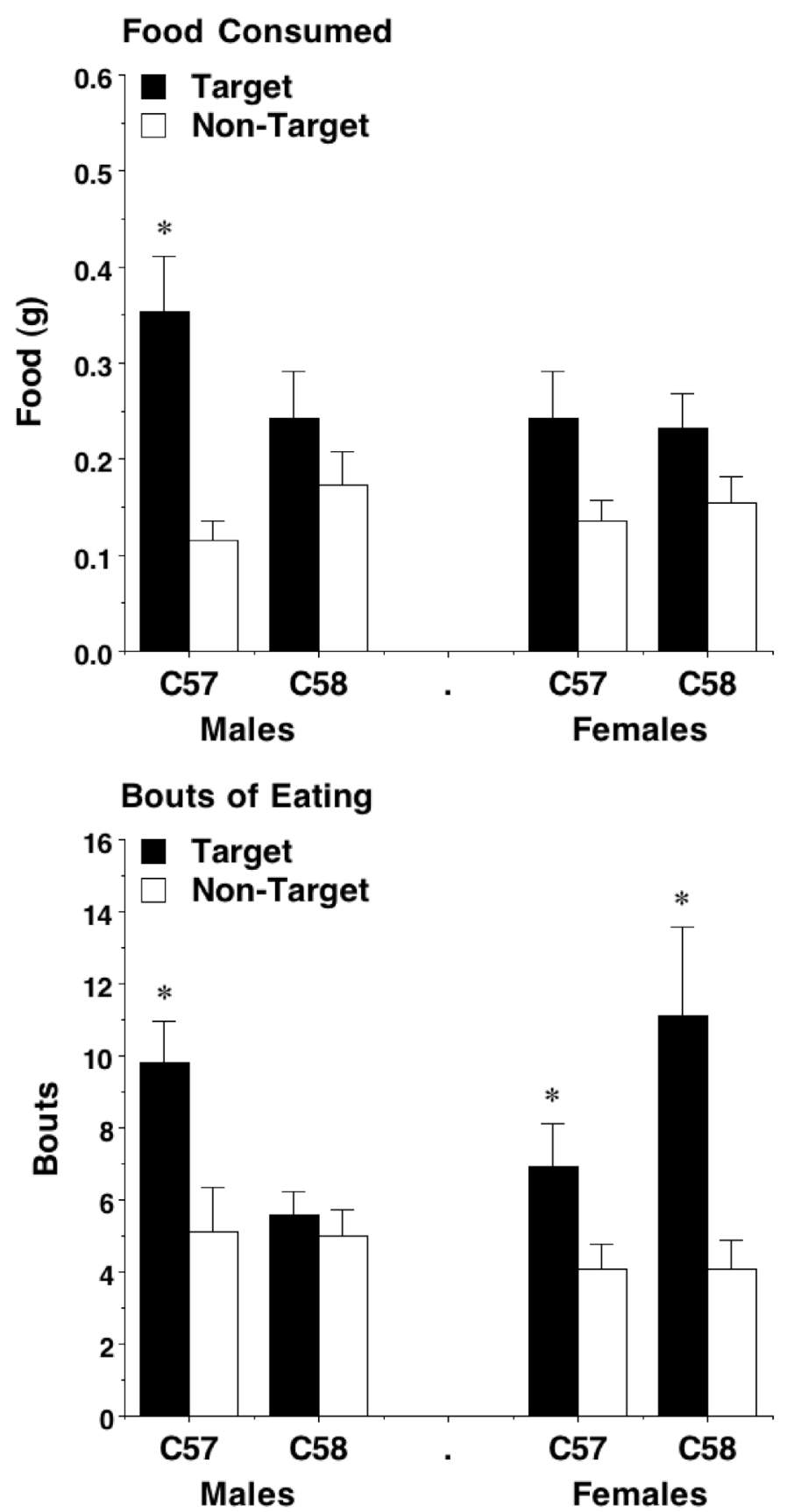

Fig 5. The amount of food eaten and the number of eating bouts in a social transmission of food preference assay

Male C57BL/6J mice, but not male C58/J mice, had significant preference for the target food. No strain effects were found in the female groups. Data shown are mean + SEM for a 1-hr test. $* \mathrm{p}<0.05$ vs. within-strain comparison, target vs. non-target food. 
Table 1

\section{Maternal and pup behaviors measured in C57BL/6J and C58/J mice}

\begin{tabular}{|c|c|}
\hline Maternal behaviors & Corresponding pup behaviors \\
\hline \multicolumn{2}{|l|}{ Time spent with pups (sec) } \\
\hline Pups huddled together after trial (\%) & Pup leaving nest (bouts) \\
\hline Self-groom (bouts) & Self-groom (bouts) \\
\hline Jumps (\#) & Jumps (\#) \\
\hline Upright scrabbles $a$ (bouts) & Upright scrabbles $^{a}$ (bouts) \\
\hline Back flips $^{b}(\#)$ & Rearing (\#) \\
\hline \multicolumn{2}{|l|}{ Head weaves or bobs (\#) } \\
\hline Digging in bedding (bouts) & Digging in bedding (bouts) \\
\hline Chewing on nestlet (bouts) & Chewing on nestlet (bouts) \\
\hline Pup licking (bouts) & Allogrooming (bouts) \\
\hline \multicolumn{2}{|l|}{ Huddling over/nursing pups (bouts) } \\
\hline \multicolumn{2}{|l|}{ Picking up pup (bouts) } \\
\hline \multicolumn{2}{|l|}{ Move a pup with mouth (bouts) } \\
\hline \multicolumn{2}{|l|}{ Move a pup with paws (bouts) } \\
\hline Move bedding to a pup (bouts) & \\
\hline
\end{tabular}




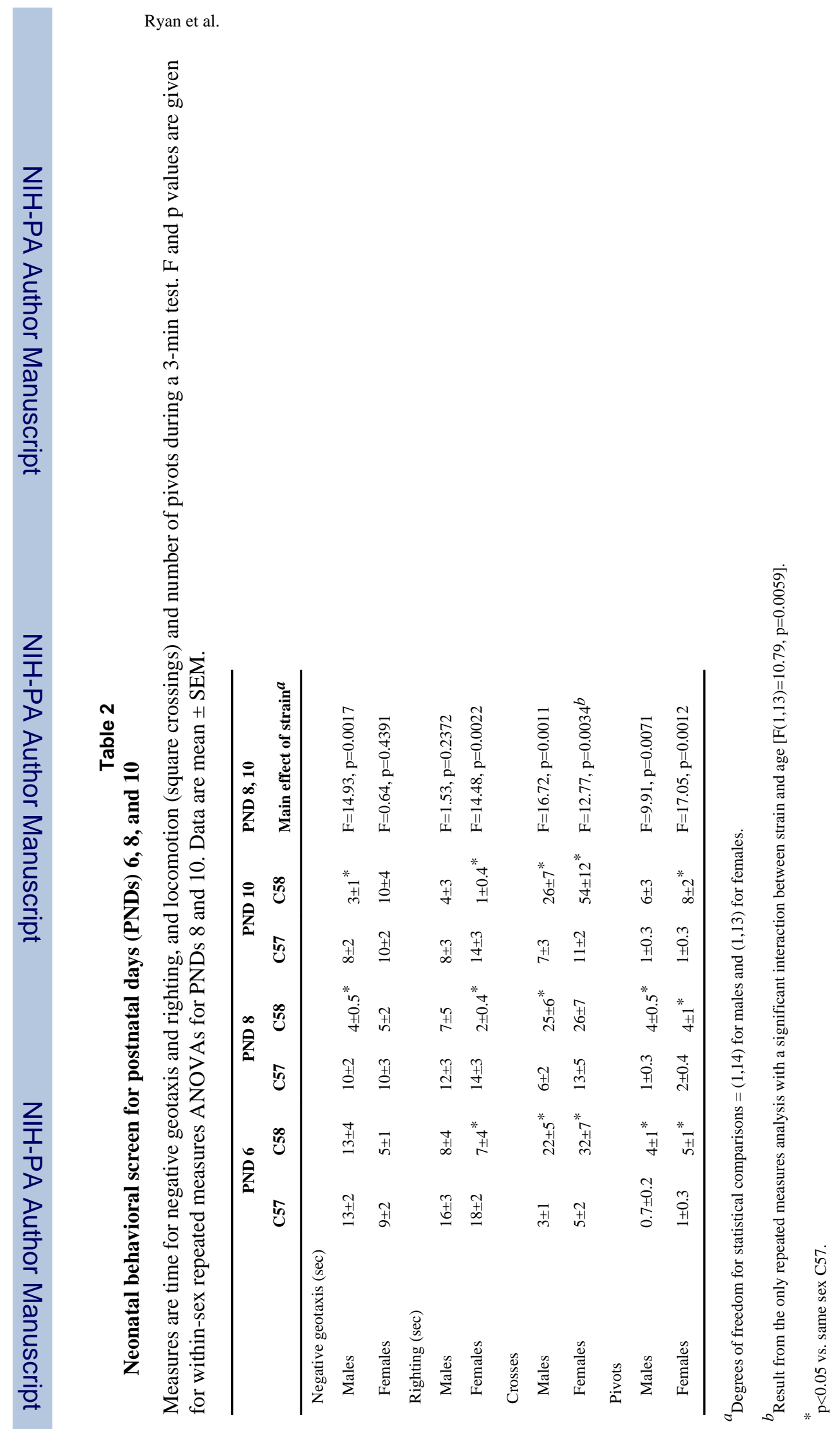

Page 23 
Table 4

Occurrence of repetitive behaviors in young adult $\mathrm{C57BL} / 6 \mathrm{~J}$ and $\mathrm{C58} / \mathrm{J}$ mice in social and non-social testing conditions

\begin{tabular}{lcccc}
\hline & \multicolumn{2}{c}{ Males } & \multicolumn{2}{c}{ Females } \\
& C57 & C58 & C57 & C58 \\
\hline Olfactory test ${ }^{a}$ & & & & \\
Number of mice & 16 & 26 & 14 & 18 \\
Jumping & $0 \%$ & $77 \%^{*}$ & $7 \%$ & $72 \%^{*}$ \\
Digging in bedding & $88 \%$ & $42 \%^{*}$ & $93 \%$ & $33 \%^{*}$ \\
Chewing bedding & $100 \%$ & $85 \%$ & $100 \%$ & $89 \%$ \\
Chewing cotton swab & $13 \%$ & $8 \%$ & $0 \%$ & $0 \%$ \\
Climbing cotton swab & $0 \%$ & $8 \%$ & $7 \%$ & $16 \%$ \\
Social choice test ${ }^{b}$ & & & & 18 \\
Number of mice & 16 & 26 & 13 & $83 \%^{*}$ \\
Jumping (\%) & $0 \%$ & $88 \%^{*}$ & $8 \%$ & $8.89 \pm 0.74^{\#}$ \\
Grooming bouts & $5.81 \pm 0.66$ & $9.96 \pm 0.64^{\#}$ & $5.00 \pm 0.44$ & \\
STFP test ${ }^{c}$ & & & & 16 \\
Number of mice & 16 & 24 & 13 & $69 \%^{*}$ \\
Jumping (\%) & $6 \%$ & $88 \%^{*}$ & $8 \%$ & \\
\hline
\end{tabular}

${ }^{a}$ Olfactory habituation/dishabituation test.

${ }^{b}$ Three-chambered social choice test.

${ }^{c}$ Social transmission of food preference test.

${ }^{*} \chi^{2}<0.05$ vs. C57BL/6J mice of the same sex.

${ }_{\mathrm{p}}<0.05$ vs. C57/BL6J mice of the same sex. 